\section{Ad libitum intake of hydroelectrolytes and energy replenishers in horses submitted to marcha training.}

\author{
Ingestão ad libitum de repositores hidroeletrolíticos e \\ energéticos em cavalos submetidos ao treinamento de marcha
}

\author{
Marcel Ferreira Bastos Avanza**, Bruna Maria Ribeiro², Lorena Chaves Monteiro³, Micheline Ozana da Silva4, \\ Waleska de Melo Ferreira Dantas ${ }^{5}$, Pedro Ancelmo Nunes Ermita ${ }^{5}$, Samuel Rodrigues Alves², \\ Hélio Cordeiro Manso Filho ${ }^{6}$, Rinaldo Batista Viana ${ }^{7}$ \& José Dantas Ribeiro Filho ${ }^{1}$ \\ 'Veterinarians, DSc, Professors. Departamento de Veterinária - DVT, Centro de Ciências Biológicas e da Saúde - CCB, \\ Universidade Federal de Viçosa - UFV, Viçosa, MG, Brasil \\ ²Veterinarian, MSc. Departamento de Veterinária - DVT, Centro de Ciências Biológicas e da Saúde - CCB, Universidade Federal \\ de Viçosa - UFV, Viçosa, MG, Brasil \\ ${ }^{3}$ Veterinarian. Departamento de Veterinária - DVT, Centro de Ciências Biológicas e da Saúde - CCB, Universidade Federal de \\ Viçosa - UFV, Viçosa, MG, Brasil \\ ${ }^{4}$ Physiotherapist, DSc. Departamento de Veterinária - DVT, Centro de Ciências Biológicas e da Saúde - CCB, Universidade \\ Federal de Viçosa - UFV, Viçosa, MG, Brasil \\ ${ }^{5}$ Veterinarians, DSc. Departamento de Veterinária - DVT, Centro de Ciências Biológicas e da Saúde - CCB, Universidade Federal \\ de Viçosa - UFV, Viçosa, MG, Brasil \\ ${ }^{6}$ Veterinarian, PhD, Professor. Núcleo de Pesquisa Equina - NPE, Departamento de Zootecnia - DZO, Universidade Federal \\ Rural de Pernambuco - UFRPE, Recife, PE, Brasil \\ `Veterinarian, DSc, Professor. Instituto da Saúde e Produção Animal - ISPA, Universidade Federal Rural da Amazônia - UFRA, \\ Belém, PA, Brasil
}

\begin{abstract}
This study aimed to measure the ad libitum intake of hydroelectrolytes and energy replenishers containing different concentrations of sucrose, dextrose, and maltodextrin in six Mangalarga Marchador horses subjected to gait training. The animals were distributed between three treatments in a $6 \times 3$ crossover design (six animals/three treatments). After exercising, the animals were sent to individual stalls where they received their respective treatments: Water (control), hydroelectrolytes and energy replenishers 1 (HES1), or hydroelectrolytes and energy replenishers 2 (HES2). The volume ingested and the animal's serum levels of sodium, potassium, chloride, ionized calcium, magnesium, and phosphorus were measured. Data were collected at the following times: $\mathrm{TO}$, just before exercising; $\mathrm{Tl}$, immediately after exercising; T2, $2 \mathrm{~h}$ after exercising; T4, $4 \mathrm{~h}$ after exercising; and T6, $6 \mathrm{~h}$ after exercising. The ingested volumes of HES1 and HES2 were similar to those of the control group, demonstrating good palatability. In addition, no adverse effects were detected.
\end{abstract}

Keywords: equine, exercise, electrolyte, carbohydrate, sports drink.

\section{Resumo}

O presente estudo teve como objetivo aferir o volume ingerido a libitum de repositores hidroeletrolíticos contendo diferentes concentrações de sacarose, dextrose e maltodextrina em equinos submetidos ao treinamento de marcha. Foram utilizados seis equinos Mangalarga Marchador em treinamento de marcha. Os animais foram distribuídos nos três tratamentos em sistema cross over $6 \times 3$ (seis animais / três tratamentos). Após o exercício os animais eram encaminhados às baias individuais, onde receberam os respectivos tratamentos: Água (controle); Repositor Hidroeletrolítico e Energético 1(HES1) e Repositor Hidroeletrolítico e Energético 2 (HES2). Foram mensurados o volume espontaneamente ingerido, sódio, potássio, cloreto, cálcio ionizado, magnésio e fósforo séricos. As avaliações foram realizadas nos tempos: TO: antes do início do exercício; T1: após o término do exercício; T2: duas horas após o exercício; T4: quatro horas após o exercício e T6: seis horas após o exercício. O volume ingerido de HES1 e HES2 foram similares aos do grupo controle, demonstrando boa palatabilidade, sem ocasionarem o aparecimento de efeitos adversos.

Palavras-chave: equinos, exercício, eletrólitos, carboidratos, bebida esportiva. \section{BJ $\mathbb{M}$ Brazilian Journal of Veterinary Medicine \\ p-ISSN 0100-2430 e-ISSN 2527-2179

How to cite: Avanza, M. F. B., Ribeiro, B. M. Monteiro, L. C., Silva, M. O., Dantas, W. M. F., Ermita, P. A. N., Alves, S. R., Manso Filho, H. C., Viana, R. B. \& Ribeiro Filho, J. D. (2018). Ad libitum intake of hydroelectrolytes and energy replenishers in horses submitted to marcha training. Brazilian Journal of Veterinary Medicine, 40, e033318. doi: 10.29374/2527-2179.bjvm033318

Financial support: Fundação de Amparo à Pesquisa do Estado de Minas Gerais (FAPEMIG).

Conflict of interests: No conflict of interests declared concerning the publication of this article.

Received: November 07, 2017.

Accepted: January 12, 2018

The study was carried out at Haras San Genaro, São Geraldo, Minas Gerais, and at the Laboratório de Pesquisa em Medicina Interna Veterinária - DVT, Universidade Federal de Viçosa - UFV, Viçosa, MG, Brasil.

\section{*Correspondence}

Marcel Ferreira Bastos Avanza

Departamento de Veterinária - DVT, Centro de Ciências Biológicas e da Saúde - CCB, Universidade Federal de Viçosa - UFV Av. PH Rolfs, s/n, Centro CEP 36570-977 - Viçosa (MG), Brasil E-mail:marcel.avanza@gmail.com

Copyright Avanza et al. This is an Open Access article distributed under the terms of the Creative Commons Attribution Non-Commercial License which permits unrestricted non-commercial use, distribution, and reproduction in any medium provided the original work is properly cited. 


\section{Introduction}

Physical activity in any species generates heat and, in equines, the majority of heat dissipation occurs through perspiration (Meyer, 1995). Depending on the intensity of the exercise, ambient temperature, and humidity, losses may exceed $10 \mathrm{Lh}^{-1}$ (Hodgson, 2014). Equine sweat is a moderately hypertonic secretion in relation to plasma, and contains high concentrations of sodium, chloride, and potassium and lower concentrations of magnesium and calcium (McCutcheon \& Geor, 2014). Sweating in large volumes can therefore lead to homeostatic imbalances.

Fluid and electrolyte replacement can rehydrate the animal; it alleviates the development of muscular fatigue and raises the rate of glycogenesis, thus contributing to the improvement of the athletic performance (Lima et al., 2007). There are several studies on the physiological changes resulting from physical activity in horses, which deal with hematological alterations, hydroelectrolyte balances, and acid-base equilibriums (Teixeira-Neto et al., 2004; Wanderley et al., 2015).

Hydroelectrolyte solutions used for electrolyte replacement in equine athletes should contain adequate amounts of the major electrolytes lost through sweating, and a source of energy which can be glucose, dextrose, or maltodextrin (Lindinger \& Ecker, 2013). In Brazil, the commercial products available are pastes containing electrolytes and carbohydrates. It is common practice to administer these products to equine athletes with the goal of restoring electrolytes lost during exercise. However, there is no evidence of their effectiveness on animal performance (Sampieri et al., 2006).

The development of veterinary products for correcting the electrolyte imbalances associated with physical activity has been carried out empirically, without the use of a controlled design to certify the real effectiveness of the formulations. In this way, the challenge was set to develop a rehydrating solution containing electrolytes and energy sources for use during or after exercise, based on the losses which occur during sporting activities. The proposed electrolyte solution, unlike commercially available products, has the advantage of spontaneous ingestion by the animals. The objective of the present study was to measure the ad libitum intake of hydroelectrolytes and energy replenishers in equines subjected to marcha gait training.

\section{Materials and methods}

The experiment was carried out on a farm located in the municipality of São Geraldo, Minas Gerais, at an altitude of $380 \mathrm{~m}$, latitude $-20^{\circ} 92^{\prime} 87.12^{\prime \prime}$ and longitude $-42^{\circ} 79^{\prime} 48.89^{\prime \prime}$. The temperature varied from 12 to $31.1^{\circ} \mathrm{C}$ during the experimental period and the relative humidity from 24 to $93 \%$. Six Mangalarga Marchador horses (three males and three females) were used during the training phase for gait competition, with ages varying between four and six years, an mean body weight of $370 \mathrm{~kg}$, and good body scores (Speirs, 1997). All experimental procedures were approved by the Ethics Committee on Animal Use of the Federal University of Viçosa (CEUA 64/2014).

The animals were kept in an intensive management system and were fed on chopped elephant grass (Pennisetum purpureum), Tifton hay (Cynodon sp.), and commercial concentrate from a trough, as well as water and mineral supplements ad libitum. On the days of the experiment, the water troughs were cleaned and dried, and their supply and drainage systems were interrupted. The feeding remained the same while the mineral supplements were withdrawn, and the water or hydroelectrolyte and energy replenishers were supplied ad libitum in the water troughs of the stalls.

All the animals were mounted in the morning and trained on a flat dirt track, where they performed 10 min of walking warm-up followed by 45 min of uninterrupted marcha gait and $5 \mathrm{~min}$ of walking for recovery. After training, the animals had their harness removed, were bathed, and remained exposed for 10 min in the sun to dry. Subsequently, the animals were directed to their individual stalls where they remained for $6 \mathrm{~h}$ (treatment time). During this period the treatments were offered ad libitum. The content was measured during the experimental phase.

The six animals were randomly assigned to three treatments in a $6 \times 3$ cross-over design, with each animal undergoing all three treatments. The treatments offered to the animals were: water (the control); **hydroelectrolyte and energy replenisher 1 (HES1, containing sodium chloride, potassium chloride, sodium citrate, magnesium, calcium, dextrose, maltodextrin, and sucrose; measured osmolarity = $213 \mathrm{mOsm} / \mathrm{L}$ ); and **hydroelectrolyte and energy replenisher 2 (HES2, 
containing sodium chloride, potassium phosphate, sodium citrate, magnesium, calcium, dextrose, maltodextrin, and sucrose; measured osmolarity $=205 \mathrm{mOsm} / \mathrm{L}$ ). The replenishers offered the same elements diluted in water, except for potassium chloride in HES1 and potassium phosphate in HES2, and differed only in the quantity of the other elements. The replenishers and water were supplied ad libitum in graduated water troughs.

Serum samples for laboratory tests were collected at the following times: TO, immediately before exercising; $\mathrm{T1}$, immediately after exercising; T2, $2 \mathrm{~h}$ after the beginning of treatment; $\mathrm{T} 4,4 \mathrm{~h}$ after the beginning of treatment; and T6, $6 \mathrm{~h}$ after the beginning of treatment. Measurements of the volume of HES1, HES2, and Water ingested ad libitum were made at T2, T4, and T6.

In order to obtain serum for biochemical analyses, blood was collected after antisepsis by jugular venipuncture, using needles and BD Vacutainer blood collection tubes (Becton \& Dickinson surgical industry Ltd., Brazil), without an anticoagulant. The samples were centrifuged and the serum aliquots analyzed in an automatic multi-biochemical analyzer (HumaStar 300 - Human; distributed by In Vitro Diagnostica Ltd., Itabira, Brazil) to determine the magnesium (xylidyl blue colorimetric method, commercial reagent, Human) and phosphorus (ammonium molybdate colorimetric method, commercial reagent, Human) content. Two milliliters of blood were extracted using lithium heparin syringes (Radiometer, Copenhagen, Denmark) to measure the sodium, potassium, chloride, and ionized calcium in an ABL80 portable analyzer (Radiometer).

The statistical program SAEG 9.1 (SAEG, 2007) was used for analysis and the data were subjected to the Lilliefors and the Cochran and Bartlett tests to evaluate the normality and homogeneity of the variances, respectively, as a premise to analysis of variance (ANOVA). Where the data complied, analysis of variance was performed to evaluate the influences of exercise, treatments, and time, as well as the interaction between treatments and time. Where the results were significant, a Tukey test was applied, and where the coefficient of variance was above $15 \%$, the Duncan test was performed. Where the requirements of normality and homogeneity were not met, non-parametric analysis was performed with the Kruskal Wallis test. All analyses were interpreted considering a probability of error of $5 \%(\mathrm{P}<0.05)$.

\section{Results}

At the end of gait training, all the animals were tired and sweating. The mean volume ingested by control animals during the six hours of supply (T2 to T6) was $13.5 \pm 5.1 \mathrm{~L}$, whereas the means of the HES1 and HES2 were 19.2 \pm 8.8 and $14.9 \pm 2.7 \mathrm{~L}$, respectively (Table 1). Despite the values, no effect of the treatments or of the treatments over time was detected.

The results of the electrolyte concentration are expressed in Table 2 . A decrease in the plasma sodium value at T6 was observed in the animals of the control group when compared to those in the HES1 group $(\mathrm{P}<0.05)$. There was a reduction in potassium at T1 in the animals of all treatments $(\mathrm{P}<0.05)$. From T2, after two hours of rehydration, there was an increase in potassium values in the animals of all treatments, returning to basal values at $\mathrm{T} 4$ and $\mathrm{T} 6$. There was a decrease in chloride in the control group animals at T4 compared to the HES1 group animals $(\mathrm{P}<0.05)$. The ionized calcium presented a similar behavior to potassium, with no difference between treatments ( $\mathrm{P}>0.05)$. However, when evaluating the treatments during the experimental phase, a reduction in ionized calcium at $\mathrm{Tl}$ was observed in the animals of all treatments with a subsequent increase at $\mathrm{T} 2$, $\mathrm{T} 4$, and $\mathrm{T} 6(\mathrm{P}<0.05)$.

Table 1. Mean values and standard deviations of the ingested volumes ( $\mathrm{L}$ ) of water (control) and hydroelectrolytes and energy replenishers 1 and 2 (HES1 and HES2) by horses undergoing gait training for a duration of one hour.

\begin{tabular}{ccccc}
\hline \multirow{2}{*}{ Treatments } & \multicolumn{5}{c}{ Time } \\
\cline { 2 - 5 } & T2 & T4 & T6 & Total \\
\hline Control & $4.5 \pm 3.4$ & $5.7 \pm 5.9$ & $3.6 \pm 1.7$ & $13.5 \pm 5.1$ \\
HES1 & $4.2 \pm 5.8$ & $7.4 \pm 6.7$ & $7.5 \pm 1.9$ & $19.2 \pm 8.8$ \\
HES2 & $5.2 \pm 1.7$ & $5.2 \pm 4.9$ & $4.4 \pm 3.0$ & $14.9 \pm 2.7$ \\
\hline
\end{tabular}

T2 - two hours after the end of the training; T4 - four hours after training; T6 - six hours after training; Total - mean volume ingested per animal in each treatment. 
Table 2. Mean values and standard deviations of the electrolytes sodium (mMol L-1), potassium (mMol L-1), chloride (mMol L-1), ionized calcium ( $\mathrm{mMol} \mathrm{L}^{-1}$ ), magnesium ( $\mathrm{mg} \mathrm{dL}^{-1}$ ), and phosphorus ( $\mathrm{mg} \mathrm{dL}^{-1}$ ) of healthy horses before (TO) and after (T1) gait training for one hour and subsequently treated with water (control) or with hydroelectrolytes and energy replenishers (HES1 and HES2) ad libitum for six hours (T2, T4, T6) in a $6 \times 3$ cross-over design.

\begin{tabular}{|c|c|c|c|c|c|}
\hline \multirow[b]{2}{*}{ Treatments } & \multicolumn{5}{|c|}{ Time } \\
\hline & TO & $\mathrm{T} 1$ & $\mathrm{~T} 2$ & $\mathrm{~T} 4$ & T6 \\
\hline & \multicolumn{5}{|c|}{ Sodium $\left(\mathrm{mMol} \mathrm{L}^{-1}\right)$} \\
\hline Control & $139.3 \pm 1.00 A a$ & $138.7 \pm 1.60$ Aa & $138.8 \pm 1.70 \mathrm{Aa}$ & $137.5 \pm 1.00 \mathrm{Aa}$ & $137.8 \pm 1.20 \mathrm{Ba}$ \\
\hline HES1 & $139.5 \pm 0.80^{\text {Аа }}$ & $139.5 \pm 1.00^{\mathrm{Aa}}$ & $140.2 \pm 2.90^{\mathrm{Aa}}$ & $140.0 \pm 1.90^{\mathrm{Aa}}$ & $140.2 \pm 1.50^{\text {Аa }}$ \\
\hline \multirow[t]{2}{*}{ HES2 } & $139.2 \pm 1.00^{\mathrm{Aa}}$ & $139.5 \pm 0.80^{\mathrm{Aa}}$ & $139.7 \pm 2.00^{\mathrm{Aa}}$ & $139.0 \pm 1.90^{\mathrm{Aa}}$ & $138.8 \pm 1.50^{\mathrm{ABa}}$ \\
\hline & \multicolumn{5}{|c|}{ Potassium (mMol L') } \\
\hline Control & $4.0 \pm 0.2 \mathrm{O}^{\mathrm{Aa}}$ & $3.5 \pm 0.20^{\mathrm{Ab}}$ & $3.6 \pm 0.50^{\mathrm{Aab}}$ & $4.0 \pm 0.2 \mathrm{O}^{\mathrm{Aa}}$ & $4.0 \pm 0.20^{\mathrm{Aa}}$ \\
\hline HES1 & $3.9 \pm 0.20^{\mathrm{Aa}}$ & $3.5 \pm 0.10^{\mathrm{Ab}}$ & $3.8 \pm 0.40^{\mathrm{Aab}}$ & $4.0 \pm 0.20^{\mathrm{Aa}}$ & $4.0 \pm 0.10^{\mathrm{Aa}}$ \\
\hline \multirow[t]{2}{*}{ HES2 } & $3.9 \pm 0.20^{\mathrm{Aab}}$ & $3.5 \pm 0.10^{\mathrm{Ab}}$ & $3.6 \pm 0.40^{\mathrm{Aab}}$ & $3.9 \pm 0.30^{\mathrm{Aab}}$ & $4.0 \pm 0.10^{\mathrm{Aa}}$ \\
\hline & \multicolumn{5}{|c|}{ Chloride (mMol L-1) } \\
\hline Control & $98.0 \pm 1.41^{\mathrm{Aa}}$ & $95.7 \pm 1.86^{\text {Aa }}$ & $96.8 \pm 1.72^{\mathrm{Aa}}$ & $96.5 \pm 0.55^{\mathrm{Ba}}$ & $97.2 \pm 1.33^{\text {Aa }}$ \\
\hline HES1 & $98.5 \pm 1.38^{\mathrm{Aa}}$ & $97.5 \pm 2.43^{\mathrm{Aa}}$ & $98.5 \pm 1.97^{\mathrm{Aa}}$ & $99.2 \pm 2.04^{\mathrm{Aa}}$ & $99.7 \pm 2.25^{\mathrm{Aa}}$ \\
\hline \multirow[t]{2}{*}{ HES2 } & $98.3 \pm 1.37^{\mathrm{Aa}}$ & $97.2 \pm 1.60^{\mathrm{Aa}}$ & $98.2 \pm 2.14^{\mathrm{Aa}}$ & $97.8 \pm 1.83^{\mathrm{ABa}}$ & $98.2 \pm 1.94^{\mathrm{Aa}}$ \\
\hline & \multicolumn{5}{|c|}{ Ionized Calcium $\left(\mathrm{mMol} \mathrm{L}^{-1}\right)$} \\
\hline Control & $1.69 \pm 0.52^{\mathrm{Aa}}$ & $1.53 \pm 0.66^{\mathrm{Ab}}$ & $1.71 \pm 0.24^{\mathrm{Aa}}$ & $1.73 \pm 0.42^{\mathrm{Aa}}$ & $1.71 \pm 0.40^{\mathrm{Aa}}$ \\
\hline HES1 & $1.70 \pm 0.52^{\mathrm{Aa}}$ & $1.55 \pm 0.73^{\mathrm{Ab}}$ & $1.73 \pm 0.78^{\mathrm{Aa}}$ & $1.77 \pm 0.48^{\mathrm{Aa}}$ & $1.75 \pm 0.16^{\mathrm{Aa}}$ \\
\hline \multirow[t]{2}{*}{ HES2 } & $1.66 \pm 0.43^{\mathrm{Aa}}$ & $1.53 \pm 0.86^{\mathrm{Ab}}$ & $1.73 \pm 0.80^{\mathrm{Aa}}$ & $1.73 \pm 0.12^{\mathrm{Aa}}$ & $1.73 \pm 0.86^{\mathrm{Aa}}$ \\
\hline & \multicolumn{5}{|c|}{ Magnesium (mg dL ${ }^{-1}$ ) } \\
\hline Control & $3.61 \pm 0.44^{\mathrm{Aa}}$ & $3.57 \pm 0.63^{\mathrm{Aa}}$ & $3.48 \pm 0.40^{\mathrm{Aa}}$ & $3.64 \pm 0.23^{\mathrm{Aa}}$ & $3.98 \pm 0.41^{\mathrm{Aa}}$ \\
\hline HES1 & $3.57 \pm 0.39^{\mathrm{Aa}}$ & $3.46 \pm 0.34^{\mathrm{Aa}}$ & $3.58 \pm 0.53^{\mathrm{Aa}}$ & $3.68 \pm 0.18^{\mathrm{Aa}}$ & $3.94 \pm 0.37^{\mathrm{Aa}}$ \\
\hline \multirow[t]{2}{*}{ HES2 } & $3.46 \pm 0.28^{\text {Aa }}$ & $3.61 \pm 0.39^{\mathrm{Aa}}$ & $3.73 \pm 0.38^{\mathrm{Aa}}$ & $3.66 \pm 0.27^{\text {Аа }}$ & $3.47 \pm 0.50^{\mathrm{Aa}}$ \\
\hline & \multicolumn{5}{|c|}{ Phosphorus (mg dL ${ }^{-1}$ ) } \\
\hline Control & $3.68 \pm 0.49^{\mathrm{Aa}}$ & $3.48 \pm 0.66^{\mathrm{Aa}}$ & $3.87 \pm 0.92^{\mathrm{Aa}}$ & $3.57 \pm 0.47^{\mathrm{Aa}}$ & $3.07 \pm 0.48^{\mathrm{Aa}}$ \\
\hline HES1 & $3.57 \pm 0.59^{\mathrm{Aa}}$ & $3.48 \pm 0.61^{\mathrm{Aa}}$ & $3.30 \pm 0.67^{\text {Аа }}$ & $3.62 \pm 0.39^{\mathrm{Aa}}$ & $3.08 \pm 0.54^{\mathrm{Aa}}$ \\
\hline HES2 & $3.68 \pm 0.60^{\mathrm{Aa}}$ & $3.32 \pm 0.70^{\mathrm{Aa}}$ & $3.43 \pm 0.83^{\mathrm{Aa}}$ & $3.83 \pm 0.67^{\mathrm{Aa}}$ & $3.23 \pm 0.37^{\mathrm{Aa}}$ \\
\hline
\end{tabular}

Mean values and standard deviation followed by different lower case and upper case letters in the same row and column, respectively, differ statistically from each other $(\mathrm{p}<0.05)$ according to the Tukey test $(\mathrm{CV}<15 \%)$ or Duncan test $(\mathrm{CV}>15 \%)$.

The serum magnesium and phosphorus did not show differences between treatments or within the treatments during the experimental phase $(\mathrm{P}>0.05)$.

\section{Discussion}

The mean volume ingested by control animals during the six hours of supply (T2 to T6) was 13.5 L, while the treatments HES1 and HES2 had means of 19.2 and $14.9 \mathrm{~L}$, respectively (Table 1). Although the HES1 and HES2 animals consumed a larger volume than the control animals, no significant differences were detected between the treatments. The similarity in the volumes ingested between the treatments is an important finding, since it allows us to deduce that the composition of the solutions was not a limiting factor for its ingestion. Puoli Filho et al. (2007), when comparing the consumption of water and an isotonic solution containing carbohydrate by horses subjected to resistance exercises, also did not observe differences between the ingested volumes. 
A fundamental characteristic in the development of a hydroelectrolyte replenisher for spontaneous ingestion is its palatability, as this can greatly interfere with its consumption, which would compromise the effectiveness of the product. In humans, when comparing the voluntary intake of water and hydroelectrolyte replenishers containing carbohydrates, it is usually observed that the second option is consumed in greater volume (Shirreffs et al., 2005). According to the authors, this is probably due to the improved palatability of the solution caused by the presence of carbohydrates. However, this was not observed in the solutions tested in the present study, despite the presence of carbohydrates in their composition. However, it must be emphasized that in addition to carbohydrates, the sports drinks consumed by humans contain palatabilizers, potentializing their intake. Perhaps the absence of palatabilizers can explain the results obtained in the present study if the presence of carbohydrates alone in the tested solutions was not sufficient to obtain the results that were described for the sports drinks. Based on these findings, it can be inferred that if the tested solutions contained other palatabilizers, the ingested volume could possibly be superior to that of water (the control).

According to Flaminio \& Rush (1998), the amount of sodium lost through sweating is accentuated and may reach up to $8.4 \%$ of the sodium contained in the plasma, depending on the intensity and duration of the physical activity. However, since this ion accompanies the water that is lost in sweat, its plasma values can remain in the normal range, since the sodium and water losses are equivalent. This statement may explain the absence of a decrease in plasma sodium values at T1 in the animals of the present study (Table 2). Silva et al. (2009) also detected no alteration in plasma sodium in horses subjected to exercise of submaximal intensity on a treadmill.

The plasma sodium increase at T6 in the HES1 group in relation to the control was possibly caused by the presence of sodium chloride in the solution used in this treatment. The presence of sodium in sports drinks is essential, as it helps maintain body fluid volume and, in small amounts, improves water and glucose absorption and plays an important role in muscle contraction and nerve impulse conduction. The development of post-exercise sports drinks, such as HES1 and HES2, is important for health and performance, as they provide the fastest route to recovery for animals, as cited by Butudom et al. (2004).

The reduction of potassium at $\mathrm{Tl}$ in animals from all three treatment groups (Table2) indicates the loss of this electrolyte by sweating due to physical activity, as described by Coelho et al. (2011) and McCutcheon \& Geor (2014). According to these authors, the concentration of potassium in sweat can reach up to ten times more than in plasma, hence its decrease after exercise. Although the decrease in post-exercise potassium values is a classic finding, Silva et al. (2009) did not detect any alteration of plasma potassium in equines subjected to exercise of submaximal intensity on a treadmill. As the decrease of potassium after exercising (T1) was small, although significant, the rehydration of the animals even with water was sufficient to normalize their potassium values. In this case, it is likely that the interruption of potassium loss through perspiration at the end of the physical activity, associated with its decreased excretion by the kidneys through urine, may have resulted in its normalization (Guyton \& Hall, 2011).

The difference observed in the T4 plasma chloride between the control and HES1 treatments was due to the presence of chloride as a component of the HES1 electrolyte solution and its absence in the control (Table 2). This data reinforces the importance of the ingestion of hydroelectrolyte replacements after exercise, assisting with homeostasis, especially in association with high intensity exercises or those of long duration, because in these situations the loss of chloride is more pronounced.

In the overall evaluation of plasma chloride concentration, no significant differences were detected. This finding was unexpected due to the high concentration of this ion, as well as that of potassium, in equine sweat (McCutcheon \& Geor, 2014). Possibly, the intensity and the duration of the exercise were not enough to generate such an alteration. Silva et al. (2009) detected similar results to the present research in equines subjected to submaximal exercise on a treadmill.

The reduction of ionized calcium at $\mathrm{Tl}$ is due to the use of muscle cells and the loss of sweat during physical activity, especially when subjected to resistance exercises such as the marcha gait (Coelho et al., 2011; McCutcheon \& Geor, 2014). Although not found in the animals of the present study, the metabolic alkalosis caused by a loss of chloride ions can increase the avidity of calciumbinding proteins by decreasing the plasma concentration of ionized calcium (Deldar et al., 1982). 
From $\mathrm{T} 2$, with the beginning of the rehydration, there was an increase in ionized calcium values in all treatments, slowly returning to basal values. The return of ionized calcium to basal values is possibly due to the end of the physical activity, because this event interrupts the losses caused by the exercise, restoring its homeostasis.

The absence of any change in the concentrations of serum magnesium was not expected, since exercise increases the losses of this element through sweat and urine. This demonstrates that the solutions did not alter the organic homeostasis of this electrolyte and that the intensity of this exercise may not have been sufficient to cause the changes described in the literature (Nielsen \& Lukaski, 2006). There were also no alterations in phosphorus concentrations in these animals, keeping them within the reference values for equine species (Carlson \& Bruss, 2008).

\section{Conclusion}

The volumes of the HES1 and HES2 solutions ingested ad libitum by the animals were similar to those of the water, demonstrating good palatability of these solutions. Besides that, no adverse effects were observed. New tests, especially on animals subjected to physical activities that cause greater losses of water and electrolytes, should be performed to confirm the efficacy of this type of electrolyte solution in equines.

**HES1 and HES2 (Formula protected by patent)

\section{References}

Butudom, P., Schott 2nd, H. C., Davis, M. W., Kobe, C. A., Nielsen, B. D., \& Eberhart, S. W. (2004). Drinking salt water enhances rehydration in horses dehydrated by furosemide administration and endurance exercise. Equine Veterinary Journal, 34(S34), 513-518. http://dx.doi.org/10.1111/j.2042-3306.2002.tb05475.x.

Carlson, G. P., \& Bruss, M. L. Fluid, electrolyte and acid-base balance. In Kaneko, J. J., Harvey J. W. \& Bruss M. L. Clinical biochemistry of domestic animals (6th ed., p. 529-559). California: Elsevier, 2008. http://dx.doi. org/10.1016/B978-0-12-370491-7.00017-9.

Coelho, C. S., Lopes, P. F. R., Pissinati, G. L., Ramalho, L. O., \& Souza, V. R. C. (2011). Influence of physical exercise on serum electrolytes in Quarter horses submitted to team roping. Revista Brasileira de Ciência Veterinária, 18(1), 32-35. http://dx.doi.org/10.4322/rbcv.2014.117.

Deldar, A., Fregin, F. G., Bloom, J. C., \& Davanipour, Z. (1982). Changes in selected biochemical constituents of blood collected from horses participating in a 50-mile endurance ride. American Journal of Veterinary Research, 43(12), 2239-2243. PMid:7165172.

Flaminio, M. J. B. F., \& Rush, B. R. (1998). Fluid and electrolyte balance in endurance horses. The Veterinary Clinics of North America. EquinePractice,14(1), 147-158. http://dx.doi.org/10.1016/S0749-0739(17)30217-1. PMid:9561693.

Guyton, A. C., \& Hall, J. E. Urine formation by kidneys: tubular reabsorption and secretion. In Guyton A. C. \& Hall J. E. Textbook of medical physiology (12th ed., pp.323-343). Philadelphia: Saunders, 2011.

Hodgson, D. R. Thermoregulation. In D. R. Hodgson, K. H. McKeever \& C. M. McGowan. The athletic horse: principles and practice of equine sports medicine (2nd ed., pp. 108-124). Missouri: Elsevier, 2014.

Lima, C. D., Michels, M. F., \& Amorim, R. (2007). Os diferentes tipos de substratos utilizados na hidratação do atleta para melhora do desempenho. Revista Brasileira de Nutrição Esportiva, 1,73-83.

Lindinger, M. I., \& Ecker, G. L. (2013). Gastric emptying, intestinal absorption of electrolytes and exercise performance in electrolyte-supplemented horses. Experimental Physiology, 98(1), 193-206. http://dx.doi. org/10.1113/expphysiol.2012.065185. PMid:22581743.

McCutcheon, L. J., \& Geor, R. J. Thermoregulation and exercise-associated heat illnesses. In K. W. Hinchcliff, A. J. Kaneps \& R. J. Geor. Equine sports medicine and surgery basic and clinical sciences of the equine athlete (pp. 901-918). Philadelphia: Elsevier, 2014. http://dx.doi.org/10.1016/B978-0-7020-4771-8.00041-7.

Meyer, H. Alimentação de cavalos. São Paulo: Varela, 1995. 303 p.

Nielsen, F. H., \& Lukaski, H. C. (2006). Update on the relationship between magnesium and exercise. Magnesium Research, 19(3), 180-189. PMid:17172008.

Puoli Filho, J. N. P., Barros Neto, T. L., Rodrigues, P. H., \& Garcia, H. P. (2007). Parâmetros fisiológicos do desempenho de cavalos de alta performance hidratados voluntariamente com água ou solução isotônica contendo carboidrato. Brazilian Journal of Veterinary Research and Animal Science, 44(2), 122-131. http://dx.doi. org/10.11606/issn.1678-4456.bjvras.2007.26650.

Sistema para Análises Estatísticas - SAEG. (2007). SAEG: versão 9.1 - Fundação Arthur Bernardes. Viçosa: UFV. Retrieved in 2017, November 7, from http://arquivo.ufv.br/saeg/

Sampieri, F., Schott 2nd, H. C., Hinchcliff, K. W., Geor, R. J., \& Jose-Cunilleras, E. (2006). Effects of oral electrolyte supplementation on endurance horses competing in $80 \mathrm{~km}$ rides. Equine Veterinary Journal, 38(36), 19-26. http://dx.doi.org/10.1111/j.2042-3306.2006.tb05507.x. PMid:17402386. 
Shirreffs, S. M., Aragon-Vargas, L. F., Chamorro, M., Maughan, R. J., Serratosa, L., \& Zachwieja, J. J. (2005). The sweating response of elite professional soccer players to training in the heat. International Journal of Sports Medicine, 26(2), 90-95. http://dx.doi.org/10.1055/s-2004-821112. PMid:15726482.

Silva, M. A. G., Martins, C. B., Gomide, L. M. W., Albernaz, R. M., Queiroz-Neto, A., \& Lacerda-Neto, J. C. (2009). Determinação de eletrólitos, gases sanguíneos, osmolalidade, hematócrito, hemoglobina, base titulável e anion gap no sangue venoso de equinos destreinados submetidos a exercício máximo e submáximo em esteira rolante. Arquivo Brasileiro de Medicina Veterinária e Zootecnia, 61(5),1021-1027. http://dx.doi.org/10.1590/ $\underline{\mathrm{s} 0102-09352009000500002 .}$

Speirs, V. C. The alimentary tract. In V. C. Speirs. Clinical examination of horses (pp. 261-298). Philadelphia: Saunders, 1997.

Teixeira-Neto, A. R., Ferraz, G. D., Mataqueiro, M. I., Lacerda-Neto, J. C., \& Queiroz-Neto, A. (2004). Reposição eletrolítica sobre variáveis fisiológicas de cavalos em provas de enduro de 30 e 60 km. Ciência Rural, 34(5), 1505-1511. http://dx.doi.org/10.1590/S0103-84782004000500028.

Wanderley, E. K., Silva Cavalcante Bem, B., Melo, S. K. M., Gonzalez, J. C., Cordeiro Manso, H. E. C. C., \& Manso Filho, H. C. (2015). Hematological and biochemical changes in Mangalarga Marchador horses after a fourbeat gait challenge in three different distances. Journal of Equine Veterinary Science, 35(4), 259-263. http:// dx.doi.org/10.1016/j.jevs.2015.01.009. 